\title{
Eksistensi Media Pendidikan dalam Meningkatkan Kualitas Sumber Daya Manusia
}

\author{
Ahdar \\ Dosen Fakultas Tarbiyah IAIN Parepare \\ ahdar@iainpare.ac.id \\ Musyarif \\ Fakultas UAD IAIN Parepare \\ musyarif@gmail.com \\ Isna Humaerah \\ IAIN Kendari \\ isnahumaera@iainkendari.ac.id
}

\begin{abstract}
Along with the acceleration of science and technology, there will be an impact of the increasingly complex learning process, because these challenges arise from the outside in the form of assimilation and acculturation through information and communication packages produced by technology. Meanwhile, from the inside there is a transformation of attitudes and behavior for students. Then the global challenge is the demand to be independent in order to continue to exist in the competitive era. The contemporary phenomenon describes the competitive life of the competition. In this case, those who can be developed are people who have reliable human resources. The demands and insistence of humankind to
\end{abstract}


be independent and not dependent on institutions that can recruit later after entering the world of work, because considering that employment opportunities are getting narrower and unemployment is increasing. Therefore, in answering this problem, it is the educational institutions that are competent in fostering human beings to have acceptable and marketable resources. Education is an effort to nurture humans to have high intelligence, morals and skills. In the world of education has several important elements, one of which is the media. Media is a communication and information tool that can access knowledge for students. The success or failure of the learning process in the world of education is strongly influenced by the role of the media, but the role of the media is also influenced by quality and professionalism in playing it.

Keywords: Education, Media, Human Resources.

Abstrak: Seiring akselerasi ilmu pengetahuan dan teknologi, meretas dampak semakin kompleksnya proses belajar, sebab tantangan tersebut muncul dari luar berupa terjadinya asimilasi dan akulturasi lewat paket-paket informasi dan komunikasi yang dihasilkan teknologi. Sedangkan dari dalam terjadinya transformasi sikap dan tingkah laku bagi anak didik. Kamudian tantangan global adalah adanya tuntutan untuk mandiri agar dapat tetap eksis di era kompetitif. Fenomena kontemporer mendeskripsikan persaingan hidup yang kompetitif. Dalam hal ini, yang dapat menjadi maju ialah orang-orang yang memiliki sumber daya manusia yang handal. Tuntutan dan desakan umat manusia agar dapat mandiri dan tidak tergantung kepada lembaga-lembaga yang dapat merekrut nantinya setelah terjun ke dunia kerja, sebab mengingat lapangan kerja semakin sempit dan semakin membludaknya pengangguran. Oleh karena itu, dalam menjawab persoalan ini lembaga pendidikanlah yang berkompeten dalam membina manusia memiliki sumber daya akseptabel dan marketabel. Pendidikan merupakan suatu usaha membina manusia agar memiliki inteligensi yang tinggi, bermoral dan berskill. Dalam dunia pendidikan memiliki beberapa elemen penting, salah satu di antaranya adalah media. Media merupakan alat komunikasi dan informasi yang dapat mengakses ilmu pengetahuan kepada anak didik. Berhasil tidaknya proses 
belajar dalam dunia pendidikan sangat dipengaruhi oleh peran media, namun peran media juga dipengaruhi oleh kualitas dan profesional dalam memerankannya.

Kata Kunci: Pendidikan, Media, Sumber Daya Manusia

\section{Pendahuluan}

Media merupakan alat informasi dan komunikasi yang dapat mengakses data secara efektif dan efisien karena menggunakan alat bantu yang memediasi atau sebagai 'jembatan' dalam penyampaian pesan dari sumber (subyek) kepada sasaran (obyek). Adanya proses interaksi antara subyek dan obyek terimplikasi untuk saling take and give. Proses tersebut yakni saling mengisi (brainstorming) sehingga terjadi feedback yang mengarah kepada proses transformasi. Orientasi dan sasaran media berkaitan erat dalam aktivitas dunia pendidikan.

Pendidikan secara esensial adalah aktualisasi belajar mengajar. Kegiatan belajar dan mengajar bagai dua keping mata uang yang sangat erat kaitannya dan tidak bisa dipisahkan. Kalau ada proses belajar, maka pasti ada proses mengajar. Begitu juga sebaliknya, jika terjadi aktivitas mengajar maka, tentu terjadi proses belajar juga. Jadi proses belajar dapat terjadi kapan dan dimana saja serta tidak terlepas dari ada yang mengajar walau dalam keadaan tersirat. Proses belajar terjadi karena adanya interaksi individu dengan lingkungannya. Hal ini dapat dilihat, salah satu indikasi seseorang belajar sesuatu adalah adanya perubahan tingkah laku dalam dirinya. ${ }^{1}$ Perubahan tingkah laku tersebut menyangkut baik perubahan yang bersifat pengetahuan (kognitif), ketrampilan (psikomotorik), maupun yang menyangkut nilai atau sikap (afektif).

Lingkungan belajar yang diatur oleh pengajar mencakup tujuan pengajaran, bahan pengajaran, metode pengajaran dan penilaian pengajaran. Unsur-unsur tersebut dapat dikenal dalam komponen-komponen pendidikan. Dalam interaksi belajar mengajar, salah satu unsur yang

1 Arief S. Sadiman (dkk), Media Pendidikan; Pengertian, Pengembangan dan Pemanfatannya (Jakarta: Rajawali Press, 1996 ), 2. 
paling berperan adalah aspek metodologi pengajaran. Dalam metodologi pengajaran, ada dua segmen yang paling menonjol yaitu metode mengajar dan media pengajaran sebagai alat bantu pengajaran. ${ }^{2}$ Dengan demikian, menjadi bagian yang urgen dalam mengimplementasikan kegiatan pendidikan.

Media pengajaran dapat meningkatkan kegiatan proses belajar anak didik yang pada gilirannya diharapkan dapat mempertinggi hasil belajar yang dicapainya. Media pengajaran dapat mempertinggi proses belajar mengajar anak didik dengan alasan sebagai berikut:

Berkenaan dengan manfaat media pendidikan dalam proses belajar mengajar: lebih menarik sehingga dapat membangkitkan motivasi, bahan pengajaran akan lebih jelas maknanya sehingga mudah dipahami, metode pengajaran bervariasi sehingga anak didik tidak bosan dan guru tidak terkuras tenaga, anak didik lebih banyak melakukan kegiatan belajar. Yang berkenaan dengan taraf berpikir siswa, mengikuti tahap perkembangan dimulai dari berpikir kongkrit menuju berpikir abstrak, dimulai berpikir sederhana sampai berpikir kompleks. $^{3}$

Uraian tersebut di atas memberikan gambaran bahwa media pengajaran berorientasi pada peningkatan kualitas belajar mengajar. Kualitas belajar mengajar menstransmisikan out-put pendidikan yang berkualitas.

Media pengajaran berimplementasi dalam proses belajar mengajar. Media pengajaran cukup berperan dalam mengelola kegiatan dalam mencapai tujuan pengajaran. Adapun tujuan pengajaran ialah adanya transformatif individu, masyarakat dan professional. ${ }^{4}$ Tujuan tersebut berupa pengembangan individu, peningkatan masyarakat (bagian dari individu) dan perbaikan motif kerja secara professional. Olehnya itu, media pengajaran berelasi langsung pada pengembangan potensi anak

2 Nana Sudjana, Media Pengajaran, Media Pendidikan, (Cet. III; Bandung: Sinar Baru, 1997), 1.

3 Nana Sudjana, Media Pengajaran..., 3.

${ }^{4}$ Omar Muhammad at-Toumy al-Syaibany, Falsafatul Tarbiyah Islam, diterjemahkan oleh Hasan Langgulung dengan judul "Falsafah Pendidikan Islam, (Jakarta: Bulan Bintang, 1979 ), 49. 
didik agar dapat menjadi anak didik yang akseptabel, baik secara kognitif, afektif maupun secara psikomotorik.

Kualitas belajar mengajar yang baik akan membentuk kepribadian anak didik yang paripurna. Bila kreativitas belajar mengajar rendah, maka akan berkonsekuensi langsung pada kualitas out-put pendidikan yang rendah. Secara empiris bahwa proses yang tidak relevan atau kurang fair maka out-put akan kurang fair pula, dan apabila dalam proses belajar mengajar sesuai dengan mekanisme dan prosedur kerja, maka akan menghasilkan luaran optimal yang sesuai dengan sasaran yang diinginkan. Jadi kualitas belajar mengajar 'menyublimasi' anak didik yang berkualitas. Anak didik yang berkualitas otomatis mampu berperan aktif dalam mengisi setiap kekosongan pangsa pasar dan bersifat fungsional di dalam masyarakat. Apabila anak didik siap pakai di bidang spesialisasinya berarti telah memiliki sumber daya manusia yang handal.

Sumber daya manusia secara umum adalah produk dari pendidikan. Substansi pendidikan membentuk kepribadian anak yang memiliki sumber daya manusia yang handal, namun tidak semua output pendidikan melahirkan generasi yang memiliki sumber daya manusia yang unggul. Problem ini punya keterkaitan dengan komponen-komponen pendidikan pada sampai sejauh mana setiap komponen pendidikan mempunyai sinkronisasi dan relevansi dalam menjalankan kegiatan belajar mengajar terutama pada penggunaan, pengelolaan, pemilihan media pengajaran yang tepat guna.

Dari diskursus di atas, dapat dianalisis bahwa proses dan hasil belajar para anak didik menunjukkan perbedaan yang signifikan antara pengajaran tanpa media dan pengajaran dengan media. ${ }^{5}$ Oleh sebab itu, penggunaan media pengajaran dalam proses belajar mengajar sangat dianjurkan bahkan dituntut untuk meningkatkan kualitas dan mutu pengajaran. Jadi dengan penggunaan media pengajaran dilakukan secara efektif, maka meretaskan hasil yang maksimal pada anak didik dalam mengembangkan potensinya. Dari sisi ini, dapat ditarik 'benang merahnya' bahwa antara media pengajaran (pendidikan) dan sumber daya manusia memiliki hubungan yang erat. Karena media pendidikan

${ }^{5}$ Arief S. Sadiman (dkk), Media Pendidikan ..., 3. 
merupakan alat atau sarana dalam melakukan aktivitas pendidikan yang efektif dan efisien yang menjadi 'embrio' bagi pembentukan sumber daya manusia yang berkualitas.

\section{Strategi Pemanfaatan Media Pendidikan dalam Meningkat- kan Kualitas Sumber Daya Manusia}

Media merupakan sarana yang sangat penting dalam pelaksanaan pengajaran dan pendidikan. Media menjadi elemen atau komponen pendidikan yang harus diperhatikan dalam meningkatkan efektifitas pembelajaran, karena dengan media dalam pendidikan akan membantu proses belajar mengajar yang baik sehingga dapat tercapai tujuan pendidikan yang diharapkan. Dalam hal ini, Sudarwan Danim dalam bukunya dengan judul Media komunikasi Pendidikan berpendapat bahwa:

Media pendidikan meruapakan seperangkat alat bantu atau pelengkap yang digunakan oleh guru atau pendidik dalam rangka berkomunikasi dengan anak didik. Alat bantu itu disebut media pendidikan, sedangkan komunikasi adalah system penyampaiannya. ${ }^{6}$

Media pendidikan itu banyak dan bervariasi sehingga sangat diperlukan ilmu manajemen dalam mengelolanya. Dalam pengelolaan dan pemanfaatan media pendidikan menuntut kajian tersendiri, sesuai dengan kebutuhan dan tuntutan anak didik, materi yang disajikan, media yang digunakan, prosedur dan organisasi, harus merupakan bagian integral di bawah kontrol khusus para pendidik atau penyelenggara pendidikan.

Media pendidikan sebagai bagian integral dari kegiatan pendidikan memerlukan upaya manusia (guru dan tenaga kependidikan/ sekelompok professional lainnya) yang bersifat menyeluruh. Media merupakan hanya bagian dari upaya memanfaatkannya dan mengkaji kegiatan belajar mengajar berdasarkan pendekatan infrastruktur sehingga memerlukan keterampilan tersendiri. Upaya pendidikan diarahkan untuk mencapai tujuan pendidikan yang bermutu secara kualitatif, ini bukanlah aktivitas yang sederhana. Salah satu upaya yang mungkin dapat dilakukan adalah

\footnotetext{
${ }^{6}$ Sudarwan Danim, Media Komunikasi Pendidikan, (Jakarta: Bumi Aksara, 1994), 7.
} 
dengan jalan memanfaatkan media pendidikan dalam rangka efektivitas dan efisiensi manajemen pendidikan.

Dalam pemanfaatan media pendidikan, guru harus melakukan pemilihan yang tepat, karena pemilihan media harus menunjang pencapaian tujuan intruksional. Dalam pemilihan media diperlukan pertimbangan-pertimbangan seperti seberapa jauh dan lata pekerjaan yang sebenarnya perlu ditiru dalam program latihan, media apa yang paling praktis, apakah media yang akan digunakan itu relevan dengan materi pelajaran, apakah media sesuai dengan kapasitas, situasi dan kondisi anak didik, sejauhmana pencapaian anak didik harus sesuai dengan sasaran yang ditentukan, apakah nilai bahan pelajaran sepadan dengan harga media dan sebagainya. Dalam proses pemilihan media pendidikan yang efektif dan efisien, isi dan tujuan intruksional haruslah sesuai dengan karakteristik media tertentu. ${ }^{7}$

Pemilihan media pendidikan untuk kepentingan pengajaran sebaiknya memperhatikan kriteria-kriteria sebagai berikut:

1. Ketepatannya dengan tujuan pengajaran.

2. Dukungan terhadap isi bahan pengajaran.

3. Kemudahan memperoleh media

4. Keterampilan guru dalam mengaplikasikan.

5. Tersedia waktu dalam mengekspresikan.

6. Sesuai dengan taraf berpikir siswa. ${ }^{8}$

Dengan kriteria tersebut di atas, akan mempermudah pelaksanaan kegiatan belajar mengajar sehingga dalam pencapaian tujuan intruksional yang berarti.

7 R.H. Anderson, Selection Media - Another Persfektives, Improving Human Performance, Vol.3., No. 3, (Fall, 1997), h. 107. Dikutip oleh R.H. Anderson, Selection and Developing Media for Intruction, diterjemahkan oleh Yusuf Hadi dkk., Pemilihan dan Pengembangan Media Untuk Pembelajaran, (Jakarta : Rajawali, 1987), 5.

${ }^{8}$ Nana Sudjana dan Ahmad Riva'I, Media Pengajaran (Cet. III; Bandung: Sinar Baru, 1997), 5 
Dari segi teori belajar, berbagai kondisi dan prinsip-prinsip psikologis yang perlu mendapat pertimbangan pemilihan dan penggunaan media adalah sebagai motivasi, perbedaan individual, tujuan pembelajaran, organisasi, isi, persiapan sebelum belajar, emosi, partisipasi, umpan balik, penguatan (reinforcement), latihan dan pengulangan, penerapan. ${ }^{9}$

Telaah di atas mengemukakan bahwa media digunakan apabila mendukung tercapainya tujuan intruksional yang telah dirumuskan yang sesuai dengan sifat materi intruksionalnya. Oleh karena itu, media seharusnya digunakan dengan perencanaan yang sistematik supaya media dapat digunakan secara efektif dan efisien. Ada tiga langkah utama yang perlu diikuti dalam penggunaan media, yaitu persiapan sebelum menggunakan media, kegiatan selama menggunakan media, kegiatan tindak lanjut. ${ }^{10}$

Pemanfaatan media dapat berjalan dengan baik apabila disusun perencanaan dan persiapan yang baik pula. Dengan mempelajari literature yang telah disediakan, kemudian mengikut petunjuk-petunjuk teknis dan pelaksanaan yang berhubungan dengan tujuan-tujuan yang akan dicapai. Peralatan yang diperlukan juga disiapkan sebelumnya agar tidak menganggu dengan hal-hal yang mengurangi kelancaran penggunaan media. Peralatan media perlu ditempatkan dengan baik agar audience dapat memperhatikan dan menyimak dengan baik pula. Jika media digunakan secara berkelompok sebaiknya tujuan dibicarakan agar tercapai persamaan persepsi. Hal ini penting supaya perhatian dan pikiran terarah ke titik sentral yang sama.

Begitu pula dalam menggunakan media, yang perlu dijaga adalah suasana ketenangan agar terhindar dari hal-hal yang dapat menganggu perhatian dan konsentrasi. Ruangan jangan terlalu gelap supaya dapat menulis hal-hal yang penting atau menulis pertanyaan bila ada yang belum dipahami. Bila menulis atau menggambar atau resume, hindari hal-hal yang dapat mengalihkan perhatian dan sajian media yang sedang berjalan. Ketika media digunakan untuk berkelompok, maka perlu

9 Azhar Arsyad, Media Pembelajaran (Cet. III, Jakarta : Raja Grafindo Persada, 2002 ), 72 .

${ }^{10}$ Arief S. Sadiman (dkk), Media Pendidikan ..., 201. 
menjaga ketenangan dan tidak berbicara yang bisa menganggu teman yang lain dan bila ada perintah seperti menunjuk gambar, membuat garis, menyusun sesuatu dan lain-lain, sebaiknya dijalankan dengan tenang, jangan sampai menganggu teman yang lain.

Kegiatan follow up yaitu untuk menjaga apakah tujuan telah dicapai dan untuk menetapkan pemahaman terhadap materi intruksional yang disampaikan melalui media yang bersangkutan. Untuk itu, soal tes yang disediakan perlu kita kerjakan dengan segera sebelum kita lupa isi program media itu, kemudian kita cocokkan jawaban kita dengan kunci jawaban yang disediakan. Bila masih ada kesalahan sebaiknya mengulangi sajian program media yang bersangkutan. Jika belajar secara berkelompok perlu mengadakan diskusi kelompok untuk membahas jawaban soal tes atau hal-hal yang belum dipahami, kemudian ada saat tertentu yang memungkinkan melakukan tindak lanjut, misalnya dengan melakukan percobaan, melakukan observasi, menyusun sesuatu dan sebagainya.

Dari pemaparan strategi pemanfaatan media pendidikan, memberikan deskripsi bahwa dalam strategi pemanfaatan media pendidikan dilakukan sesuai dengan kebutuhan dan tututan, maka dengan pencapaian tujuan pendidikan dapat berjalan secara efektif dan efisien. Kemudian telah diuraikan sebelumnya bahwa dalam penggunaan media dibutuhkan skill, karena dengan skill yang professional, media dapat berfungsi dan berperan dengan baik. Semakin tinggi sikap professional seseorang dalam mengelola media semakin tinggi pula sikap kreativitas dalam suasana pendidikan yang dinamis. Apabila dalam pendidikan terjadi dinamika, maka sasaran utamanya adalah pembentukan kepribadian yang utama yakni memiliki sumber daya manusia yang unggul.

Bedsarakan uraian di atas, antara strategi pemanfaatan media pendidikan dan peningkatan sumber daya manusia merupakan garis siklus yang masing-masing memberikan konstribusi dan menjadi garis kontiniunitas yang tidak terputus sebagaimana berikut ini: 


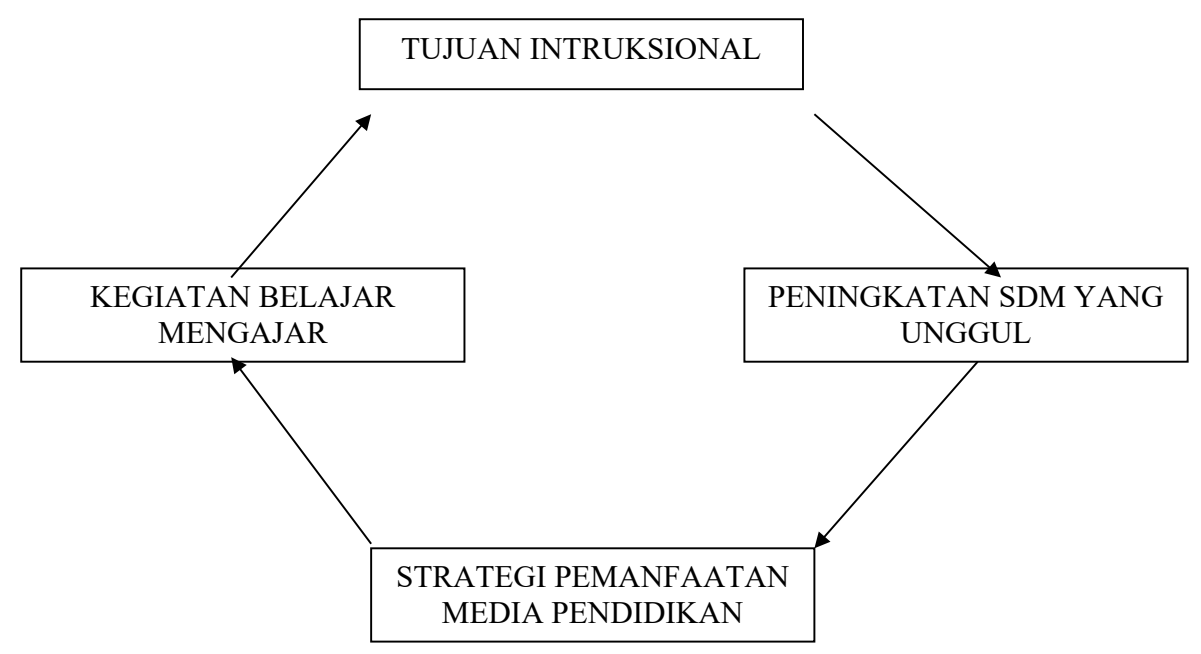

Strategi pemanfaatan media dapat dianalisis dalam membuat simpulan sebagai berikut:

a. Strategi pemanfaatan media pendidikan harus sesuai taraf berfikir anak didik.

b. Strategi pemanfaatan media pendidikan relevan dengan iklim kontemporer dan berorientasi ke depan.

c. Strategi media pendidikan sebagai wahana peningkatan moralitas, dan penggunaan teknologi modern sebagai wahana aplikatif ketika terjun ke masyarakat.

d. Memperhatikan bakat dan minat anak didik dan berorientasi profesionalisme.

e. Strategi tersebut harus menciptakan suasana ketenangan, suasana keakraban dan sebagainya.

\section{Peranan Media Pendidikan dalam Meningkatkan Kualitas Sumber Daya Manusia}

Peningkatan kualitas sumber daya manusia melalui lembaga pendidikan sangat dipengaruhi oleh peran serta media pendidikan. Olehnya itu, eksistensi dan fungsi media dalam pendidikan dan pengajaran senantiasa diarahkan pada peningkatan kualitas sumber daya manusia, 
apalagi dalam dunia pendidikan dituntut untuk melahirkan generasi yang berkualitas; beride berilyan, berakhlak mulia dan professional di bidangnya. Jadi pengadaan media pendidikan hendaknya yang mendukung peningkatan sumber daya manusia.

Media merupakan alat yang efektif dalam memberikan manfaat yang semaksimal mungkin kepada masyarakat sesuai dengan ketepatan dan besarnya pengarahan. Media tersebut dapat memainkan peranan penting dalam membina generasi dan mendorongnya untuk mengembangkan 'telaten' demi kemajuan baginya. Dan salah satu cara untuk memberantas buta wawasan pada sebagian kaum terpelajar hanya dengan bantuan media.

Secara universal, media merupakan transmisi perubahan dalam diri individu dan masyarakat. Club of Rome menerbitkan sebuah buku dengan judul The First Global Revolution, yang menjelaskan tentang prospek dan proyek media dalam sisi keehidupan umat manusia. Uraian buku tersebut meramalkan bahwa media adalah salah satu dari ketiga kekuatan utama yang akan sangat mempengaruhi umat manusia di abad $21 .{ }^{11}$ Media ada di sekeliling kita, mendominasi kita dan bahkan mempengaruhi emosi serta pertimbangan kita. Marchall Meluhan mengemukakan dalam bukunya Understanding Media the Extensi of Man, menganggap bahwa media juga menciptakan serta mempengaruhi cakupan serta bentuk hubunganhubungan dan kegiatan-kegiatan manusia. ${ }^{12}$

Seiring akselerasi ilmu pengetahuan dan teknologi, dunia semakin mengglobal dan mengarah kepada uniformitas, sains telah meretaskan media begitu menjamur sehingga media tersebut merambah ke seluruh segmen kehidupan. Ketika media banyak mampu menggeser pola kehidupan dari tersekat-sekat menjadi sejagad, dari primitif menjadi modernis, dari tradisional menjadi rasional dan sebagainya. Dobrakan transformatif dari bias media menuntut umat manusia untuk meningkatkan kehidupannya agar tetap eksis dan survival. Dampak tersebut membawa

${ }^{11}$ Lihat Seyling Wen, Future of the Media, diterjemahkan oleh Alvin Saputra, Masa Depan Media - Memahami Zaman Teknologi Informasi (Batam: Lucky ublishers, t.th), 12.

${ }^{12}$ Seyling Wen, Future of the Media..., 9. 
ke dalam iklim kompetitif yang ketat. Hal ini mendorong manusia untuk bersaing demi mempertahankan martabatnya. Bagi orang yang tidak sanggup bersaing akan tergilas oleh dinamika zaman. Olehnya itu, agar tetap eksis baik dalam kancah komunal maupun dalam tataran global, maka manusia senantiasa meningkatkan kualitasnya. Dengan demikian, korelasi peranan media dalam kehidupan mendesak agar setiap umat manusia memiliki sumber daya yang berkualitas.

Melihat kebutuhan dan tuntutan sumber daya manusia di era global, tentu perhatian dan harapan kita tertuju kepada pendidikan. Sebab, pendidikan memiliki tanggung jawab yang besar dalam kerangka membangun, membina dan mengembangkan kualitas manusia yang dijalankan secara terstruktur, sistematis dan terprogram serta berkelanjutan. ${ }^{13}$ Tuntutan dan dinamika hidup yang berkembang dalam masyarakat harus pula diiringi oleh dinamika pendidikan, bahkan pendidikan seharusnya mengarahkan dinamika masyarakat. Namun era kontemporer, lembaga pendidikan menghadapi tantangan yang besar terutama industrialisasi. Olehnya itu, pendidikan harus menghasilkan produk yang bermutu, terampil dan professional.

Kolaborasi antara media yang berbasis teknologi dan pendidikan sangat urgen, karena pendidikan yang memiliki media berbasis teknologi dapat menunjang pengajaran yang berkualitas seperti memperlancar proses belajar mengajar, memberikan dorongan untuk maju kepada anak didik, keaktifan, minat yang tinggi serta memudahkan menerima pelajaran dan menghayatinya. Senada dengan hal tersebut di atas, Yusuf Hadi Miarso dalam bukunya Teknologi Komunikasi Pendidikan, mengatakan bahwa "Media pendidikan secara umum mempunyai kegunaan untuk mengatasi hambatan dalam berkomunikasi, keterbatasan fisik dalam kelas, sikap positif peserta didik serta mempersatukan pengamatan anak didik." ${ }^{14}$

Menurut Donald P. Ely, bahwa media pendidikan mempunyai beberapa manfaat yaitu meningkatkan produktivitas pendidikan, memberi dasar

${ }^{13}$ M. Dawam Rahardjo (ed.), Keluar dari Kemelut Pendidikan Nasional - Menjawab Tantangan Kualitas SDM Abad 21, (Jakarta : Intermasa, 1997), 17.

${ }^{14}$ Yusuf Hadi Miarso, et.al., Teknologi Komunikasi Pendidikan - Pengertian dan Penerapannya di Indonesia, ( Cet. I, Jakarta : Rajawali, 1984 ), 113. 
yang lebih dinamis terhadap pendidikan, pengajaran yang lebih mantap, memungkinkan belajar seketika dan penyajian pendidikan lebih luas. ${ }^{15}$ Kemudian lebih lanjut tentang manfaat media pendidikan secara detail, Sudarwan Danim ${ }^{16}$ menjelaskan sebagai berikut :

1. Meningkatkan mutu pendidikan dengan jalan mempercepat rate of learning, membantu guru menggunakan waktu belajar secara lebih baik, mengurangi beban guru dalam menyajikan informasi, aktivitas guru lebih banyak diarahkan untuk meningkatkan kegairahan anak.

2. Memberi kemungkinan pendidikan yang sifatnya lebih individual dengan jalan memperkecil atau mengurangi kontrol guru yang tradisional dan kaku, memberi kesempatan luas kepada anak didik untuk berkembang menurut kemampuannya, memungkinkan mereka belajar menurut cara yang dikehendaki.

3. Memberi dasar pengajaran yang lebih ilmiah dengan jalan menyajikan atau merencanakan program pengajaran secara logis dan sistematis, mengembangkan kegiatan pengajaran melalui penelitian, baik sebagai pelengkap maupun sebagai terapan.

4. Pengajaran dapat dilakukan secara mantap dikarenakan meningkatnya kemampuan manusia sejalan dengan pemanfaatan media komunikasi, informasi dan data dapat disajikan lebih kongkrit dan rasional.

5. Meningkatnya perwujudan immediancy of learning, karena media dapat menghilangkan atau mengurangi jurang pemisah antara kenyataan di luar kelas dengan kenyataan di dalam kelas, memberikan pengetahuan langsung.

6. Memberikan penyajian pendidikan lebih luas, terutama melalui media massa dengan jalan memanfaatkan secara bersama dan lebih luas peristiwa-peristiwa langkah, menyajikan informasi yang tidak terlalu menekankan batas ruang dan waktu.

Uraian di atas, memberikan ilustrasi-ilustrasi penting kepada kita bahwa media pendidikan dan pemanfaatannya untuk tujuan pendidikan

${ }^{15}$ Donald P. Ely, Intruktional Design and Develovment Participant's Note Book, (Jakarta: TKPK Depdikbud, 1997 ), 17.

${ }^{16}$ Sudarwan Danim, Media Komunikasi Pendidikan ..., 13. 
mempunyai manfaat yang luas. Media pendidikan memungkinkan kegiatan belajar mengajar lebih produktif, ilmiah, diindividualisasikan, power full immediancy, sejalan dengan ilmu pengetahuan dan teknologi.

\section{Penutup}

Berangkat dari wacana sentral di atas, penulis dapat memberikan simpulan bahwa peranan media pendidikan sebagai suatu kontributor penting dalam meningkatkan sumber daya manusia sebagai berikut:

1. Media pendidikan sangat berpengaruh dalam menentukan berhasil tidaknya anak didik dalam belajar.

2. Media pendidikan banyak ragamnya, apabila dikelola secara professional akan menunjang pengembangan sumber daya manusia.

3. Media sebagai sarana penyalur informasi dan komunikasi yang mudah didapatkan, baik dalam kalangan keluarga maupun dalam lingkungan masyarakat. Hal ini berarti dapat dipakai kapan saja dalam mengembangkan potensinya.

4. Media pendidikan yang berbasis teknologi akan menunjang dalam meningkatkan sumber daya manusia.

Jadi untuk memahami Peranan media pengajaran dalam meningkatkan sumber daya manusia adalah:

a. Media pengajaran sangat berperan atau berpengaruh di dalam menentukan berhasil-tidaknya peserta didik dalam belajar.

b. Media pengajaran banyak ragamnya dan sangat berperan dalam pengembangan sumber daya manusia, bilamana dikelola secara professional.

c. Media sebagai sarana informasi dan komunikasi yang mudah didapatkan sehingga media dapat digunakan baik di lingkungan keluarga mapun di lingkungan masyarakat, hal ini berarti bahwa media dapat dipakai kapan dan di mana saja dalam pengembangan potensi peserta didik.

d. Media pengajaran yang berbasis tekhnologi akan menunjang dalam meningkatkan kualitas sumber daya manusia. 


\section{DAFTAR PUSTAKA}

Achin, A. Media Pendidikan dalam Kegiatan Belajar Mengajar, Ujung Pandang: IKIP Ujuang Pandang, 1986.

Anderson, R.H. Selection and Developing Media for Intruction, diterjemahkan oleh usuf Hadi dkk., Pemilihan dan Pengembangan Media Untuk Pembelajaran, Jakarta : Rajawali, 1987.

Ali, Muh. Kamus Lengkap Bahasa Indonesia Modern, Jakarta: Pustaka Amani, t.th.

Arsyad, Azhar. Media Pengajaran, Cet. II, Jakarta: Raja Grafindo Persada, 1995.

Azra, Azyumardi. Pendidikan Islam - Tradisi dan Modernisasi Menuju Indonesia Baru, Cet. II; Jakarta: Logos Wacana Ilmu, 2000.

Barthos, Basir. Manajemen Sumber Daya Manusia - Pendekatan Makro, Cet. I; Jakarta: Bumi Aksara, 1993.

Danim, Sudarman. Media Komunikasi Pendidikan, Jakarta: Bumi Aksara, 1995.

Daradjat, Zakiah. Ilmu Pendidikan Islam, Cet. II; Jakarta: Bumi Aksara, 1992 .

Departemen Agama RI. Al-Qur'an dan Terjemahan, Jakarta: Proyek Pengadaan Kitab Suci Al-Qur'an, 1979.

Efendi Sofyan, dkk. (ed). Membangun Martabat Manusia - Peranan Ilmuilmu Sosial dalam Pembangunan, Cet. III; Yogyakarta: Gajah Mada University Press, 1996.

Ely, Donald P. Intruktional Design and Develovment Participant's Note Book, Jakarta: TKPK Depdikbud, 1997.

Faisal, Yusuf Emir. Reorientasi Pendidikan Islam, Jakarta: Gema Insani Press, 1995.

Hadi, Sutrino. Metode Research, jilid I, Yogyakarta: UGM, 1980.

Hamalik, Oemar. Media Pendidikan, Cet. VI; Bandung: Citra Adiyah Bakti, 1989. 
Harahap, Syahrin. Islam Dinamis - Menegakkan Nilai-nilai Ajaran AlQuran dalam Kehidupan Modern di Indonesia, Yogyakarta: Tiara Wacana Yogyakarta, 1997.

Haryanto. Perencanaan Pengajaran, Cet. I; Jakarta: Rineka Cipta, 1997.

Jalaluddin dan Usman Said. Filsafat Pendidikan Islam, Cet. II; Jakarta: PT. Raja Grafindo Persada, 1996.

Langgulung, Hasan. Peralihan Paradigma dalam Pendidikan Islam dan Sains Sosial, Jakarta: Gaya Media Pratama, 2002.

Linrung, Tamsil. et.al.. ICMI - Beberapa Catatan Kritis, Jakarta: IKAPI, 1995.

Marimba, Ahmad D. Pengantar Filsafat Pendidikan Islam, Bandung: Al - Ma’arif, 1989.

Miarso, Yusuf Hadi. et.al.. Teknologi Komunikasi Pendidikan - Pengertian dan Penerapannya di Indonesia, Cet. I; Jakarta: Rajawali, 1984.

MPR RI. Tap MPR - Hasil Sidang Umum MPR RI Tahun 1999, Jakarta: Pabelan, 1999.

Muhaimin. Paradigma Pendidikan Islam - Upaya Mengefektifkan PAI di Sekolah, Bandung: Remaja Rosda Karya, 2001.

Muhammad, Afif. Islam "Mazhab" Masa Depan - Menuju Islam Non Sektarian, Bandung: Pustaka Hidayah, 1998.

Nata, Abuddin. Paradigma Pendidikan Islam, Jakarta: PT. Grasindo kerja sama IAIN Syahid Jakarta, 2001.

Percival, Ferd., dan Henry Ellington. A Handback of Educationally Technology, diterjemahkan oleh Soedjarwan S. dengan judul “ Teknologi Pendidikan", Jakarta: Air Langga, 1988.

Poerwadarminto, W.J.S. Kamus Umum Bahasa Indonesia, Cet. X; Jakarta: Balai Pustaka, 1987.

Rahardjo, M. Dawam., et.al. Keluar dari Kemelut Pendidikan - Menjawab Tantangan Kualitas SDM Abad XXI, Jakarta: IKAPI, 1997.

Rahman Getteng, Pendidikan Islam dalam Pembangunan, Ujung Pandang, Al-Ahkam, 1997. 
Sadiman, Arief S., et.al. Media Pendidikan - Pengertian, Pengembangan dan Pemanfaatan, Cet. IV; Jakarta: Raja Grafindo Persada, 1996.

Salim, Emil. Pembangunan Berwawasan Sosial, Jakarta: LP3ES, 1986.

Salim, Emil, Sumber Daya Manusia dalam Persfektif - Dalam Mencari Strategi Pembangunan Pendidikan Nasional Menjelang Abad XXI, Jakarta : Grasindo, 1991.

Sudjana, Nana., dan Ahmad Riva'I. Media Pengajaran, Cet. III; Bandung: Sinar Baru, 1997.

Sudjana, Nana., et.al.. Media Pengajaran, Cet. II, Bandung: Sinar Baru, 1991.

Sudjana, Nana. Media Pengajaran, Media Pendidikan, Cet. III, Bandung : Sinar Baru, 1997.

Syaibany, Omar Muhammad at-Toumy al-, Falsafatul Tarbiyah Islam, diterjemahkan oleh Hasan Langgulung dengan judul "Falsafah Pendidikan Islam, Jakarta: Bulan Bintang, 1979.

Tilaar, H.A.R. (ed.), Pendidikan dalam Pembangunan Nasional Menyongsong Abad XXI, Jakarta: Balai Pustaka, 1990 .

Tim Perumus Fakultas Teknik UMJ, Al - Islam dan Iptek II, ( Jakarta : Raja Grafindo Persada, 1998 ), h. Arief S. Sadiman (dkk), Media Pendidikan - Pengertian, Pengembangan dan Pemanfatannya, Jakarta: Rajawali Press, 1996.

Weiner, Myron. Modernisasi Dinamika Pertumbuhan, Yogyakarta: Gajah Mada University Press, 1980.

Wen, Sayling. Future of Education, diterjemahkan oleh Arvin Saputra dengan judul Masa Depan Pendidikan, Batam Centre: Lucky Publishers, 2003.

Winkels, W.S. Psikologi Pengajaran, Cet. IV; Jakarta: PT. Raja Grafindo Persada 1996. 
